\title{
Effect of Cell Density and Benzyl Amino Purine on the Growth of Somatic Embryo of Citrus Mandarin Batu 55 (Citrus reticulata Blanco.) in Liquid Culture
}

\author{
Nawafila Februyani ${ }^{1}$, Wahyu Widoretno ${ }^{2 *}$, Serafinah Indriyani ${ }^{2}$ \\ ${ }^{1}$ Master Program of Biology, Faculty of Mathematics and Natural Sciences, University of Brawijaya, Malang, Indonesia \\ ${ }^{2}$ Department of Biology, Faculty of Mathematics and Natural Sciences, University of Brawijaya, Malang, Indonesia
}

\begin{abstract}
Citrus mandarin Batu 55 (Citrus reticulata Blanco.) is one of Indonesian fruits commodities that have high economic value and consumers demand. The propagation of citrus mandarin by plant tissue culture generally was carried out on solid medium. The liquid culture system could increase cell multiplication therefore it became alternative method of plant propagation through somatic embryogenesis. The effect of initial cell density and Benzyl Amino Purin (BAP) concentration in liquid media were investigated. The initial cells density and right concentration of BAP given in media can increase cell proliferation of somatic embryo in liquid culture. Globular somatic embryo were cultured on Murashige and Tucker media with initial cell density $4,6,8$ and $10 \mathrm{mgL}^{-1}$ and BAP $0,0.25,0.5$, and $0.75 \mathrm{mgL}^{-1}$. Growth evaluation of somatic embryo were obtained by weighing fresh and dry weight every 2 weeks for 8 weeks for initial cell density treatment and 6 weeks of BAP treatment. The result of the research showed that cell density affect the growth of somatic embryo of citrus mandarin. Somatic embryo with low cell density showed slower growth compared than high cell density. Peak growth occured in $6^{\text {th }}$ cultured with cell density $10 \mathrm{mgL}^{-1}$. In addition to cell density, the growth of somatic embryo in liquid culture was affected by BAP. The growth of somatic embryo on the media containing BAP showed better results than without BAP. The highest BAP concentration on media showed fresh and dry weight of somatic embryo increased. In this research, growth of somatic embryo is not optimal yet because fresh and dry weights of somatic embryo still increase with high concentration $0.75 \mathrm{mgL}^{-1}$ of BAP.
\end{abstract}

Keywords: Benzyl Amino Purine, cell density, citrus mandarin, liquid medium, somatic embryo.

\section{INTRODUCTION}

Citrus mandarin (Citrus reticulata B.) is one of Indonesian fruit commodities that has high economic value and consumers demand [1]. Citrus mandarin high vitamin and sweet taste [2]. But, some problems faced in cultivation of citrus mandarin found are limited land provision, low seedlings available, and a difficulty to get well seeds for high quality crops. Propagation of citrus mandarin has been developed by plant tissue technology through somatic embryogenesis. Generally, this technique using solid medium which has several disadvantage that are the low absorption of nutrients and easily accumulated toxic compounds [3].

Culture in liquid medium has several benefits including high multiplication of cells, the entire cell surface is in direct contact with the medium, better aeration, and there is no gradient nutrients and gas in the medium [4]. Liquid

\footnotetext{
* Correspondence author: Wahyu Widoretno

Email : wahyu_widoretno@yahoo.com

Address : Dept. of Biology, University of Brawijaya, Jl. Veteran Malang, 65145
}

culture system have the potency for bioreactor culture, alternative method of micropropagation of citrus mandarin [5].

Initial cell density and growth regulators on media are important factors that affect the growth and development of cells in liquid medium [7]. Cell density during early inoculation effects the growth of somatic embryo in liquid culture [8]. In general, low cell density causes low proliferation, but high cell density inhibit cell growth because of accelerate accumulation of toxic compound in liquid culture, resulted of an imbalance between medium and cell density in the medium [8]. The highest multiplication of somatic embryo of Citrus suhuinensis and Citrus kalamondin were obtained at cell denisty $4-6$ $\mathrm{mgL}^{-1}$ and 2 - $6 \mathrm{mgL}^{-1}$, respectively [2].

Benzyl Amino Purine (BAP) is one of the cytokinin compounds to induce and stimulate the growth of citrus somatic embryos. The previous report showed that $1.5 \mathrm{mgL}^{-1} \mathrm{BAP}$ increased multiplication of somatic embryo of $C$. aurantifolia on solid media whereas $0.1 \mathrm{mgL}^{-1}$ BAP increased the multiplication of somatic embryo $C$. suhuinensis [4]. The objective of the research was to 
study the effect of initial cell density and BAP on the growth of somatic embryo in liquid culture.

\section{MATERIALS AND METHODS}

Induction and Multiplication of Somatic Embryo

Somatic embryo were induced from nucellus explants cultured on MT (Murashige and Tucker) medium $+50 \mathrm{gL}^{-1}$ sucrose $+3 \mathrm{mgL}^{-1} \mathrm{BAP}+50 \mathrm{mgL}^{-1}$ malt extract. The culture was incubated at room temperature $24^{\circ} \mathrm{C}$ for two months [8]. Formed somatic embryo was subcultured on MT medium $+30 \mathrm{gL}^{-1}$ sucrose every 6 weeks for 2-3 times.

\section{Treatment of cell density and BAP concentration}

Globuler stage of somatic embryo were subcultured on liquid media $\mathrm{MT}+30 \mathrm{gL}^{-1}$ sucrose with treated cell density of $4,6,8$, and $10 \mathrm{mgL}^{-1}$. The cell density that resulted best growth of somatic embryo is used as basis for further experiment treatment.

BAP treatment was done with the globular stage somatic embryo subculture (best cell density) in liquid media $\mathrm{MT}+30 \mathrm{gL}^{-1}$ sucrose $+0,0.25$, 0.5 , and $0.75 \mathrm{mgL}^{-1} \mathrm{BAP}$. Culture was incubated on temperature $24^{\circ} \mathrm{C}$ and homogenated by using shaker on $230 \mathrm{rpm}$. Growth was evaluated by weighing fresh and dry weight of somatic embryo every 2 weeks for 8 weeks for cell density treatment and 6 weeks for BAP treatment.

\section{Data Analysis}

This study used a randomized complete block design with repetition as a group. Factors used were initial cell density and BAP concentration. Data were analyzed using ANOVA and Duncan advanced test using significance $\alpha<0.05$.

\section{RESULT AND DISCUSSION}

Somatic embryo in liquid culture showed a friable texture and white color (Fig. 1). Initial cell density of somatic embryo affected cell growth and proliferation of somatic embryo in liquid culture. The growth of somatic embryo at high initial cell density was better than low initial cell density (Fig. 1).

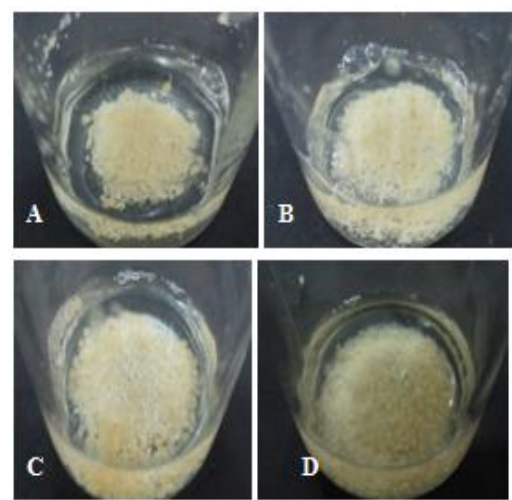

Figure 1. The growth of somatic embryo with different initial cell density at 6 weeks of culture in liquid media; A. $4 \mathrm{mgL}^{-1}$;B. $6 \mathrm{mgL}^{-1}$; C. $8 \mathrm{mgL}^{-1}$; D. $10 \mathrm{mgL}^{-1}$

The inoculation of culture with different initial cell density affected fresh and dry weight of somatic embryo in liquid culture. The growth of somatic embryo at low initial cell density was slow, while at high initial cell density it was faster. The optimum fresh weight of somatic embryo was at 6 weeks of culture and decreased after 6 weeks of culture (Fig. 2A), but the dry weight of somatic embryo still continue to increase until 8 weeks culture (Fig.2B).

The multiplication of somatic embryo with 10 $\mathrm{mgL}^{-1}$ initial cell density was higher than the others, whereas the culture with $4 \mathrm{mgL}^{-1}$ cell density result the lowest multiplication of somatic embryo. Fresh and dry weights of somatic embryo in culture with initial cell density $10 \mathrm{mgL}^{-1}$ were 2.93 $\mathrm{g}$ and $0.15 \mathrm{~g}$.
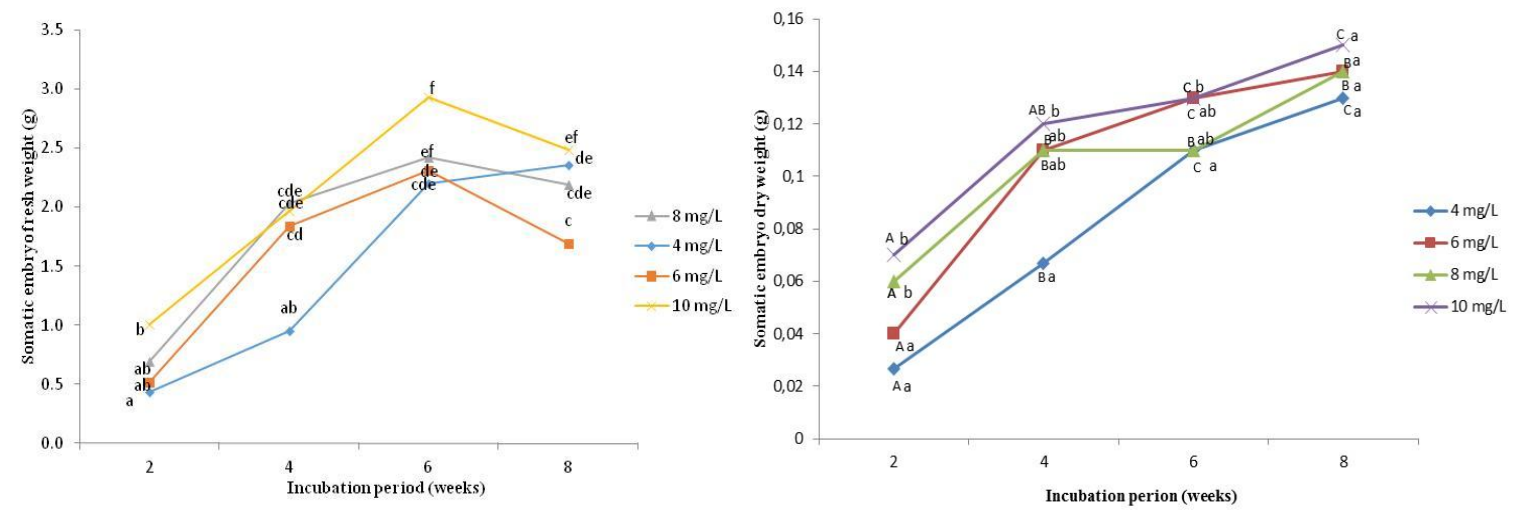

Figure 2. Fresh and dry weight of somatic embryo for 8 weeks in liquid culture; A. Fresh weight, B. Dry weight; The same letter for cell density and incubation period showed no significantly different by Duncan test $\alpha<0.05$. 
Conversely, fresh and dry weight of somatic embryo in culture with cell density $4 \mathrm{mgL}^{-1}$ was only $2.20 \mathrm{~g}$ and $0.11 \mathrm{~g}$ (Fig. 2). The optimum multiplication of somatic embryos was obtained 6 weeks incubation period and initial cell density $10 \mathrm{mgL}^{-1}$.

Beside cell density, BAP also increased the growth of somatic embryo in liquid culture. The growth of somatic embryos in luquid medium with the addition of BAP was better than without BAP (Fig. 3).

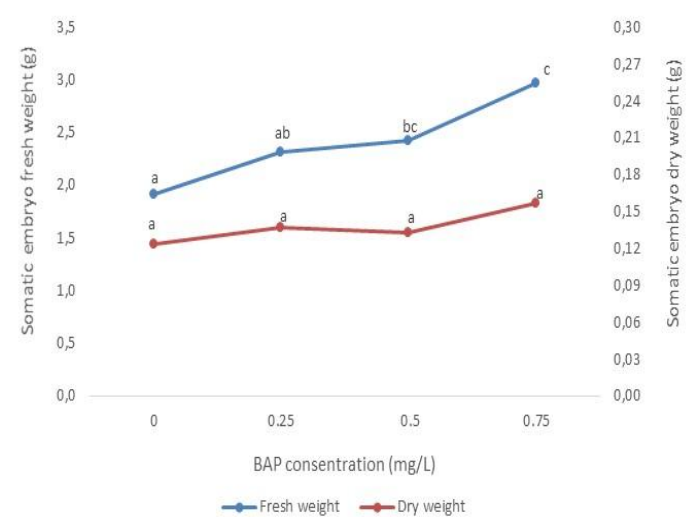

Figure 3. Fresh and dry weight of somatic embryo in liquid culture without BAP in the 6 weeks; The same letter for fresh and dry weight showed no significantly different by Duncan test $\alpha<0.05$

The growth of somatic embryo on media which added with various concentrations of BAP was observed by measuring the fresh and dry weight at 6 weeks cultures. The growth of somatic embryo on medium with the addition of BAP resulted better than without BAP. The higher concentration of BAP on media, the increasing of somatic embryo the optimum growth was higher. Fresh and dry weight of somatic embryo in liquid medium containing $0.75 \mathrm{mgL}^{-1}$ BAP were $2.97 \mathrm{~g}$ and $0.17 \mathrm{~g}$. Otherwise, fresh and dry weight of somatic embryo on media without BAP were only $2.01 \mathrm{~g}$ and $0.11 \mathrm{~g}$. However, the optimum growth of somatic embryo in liquid media containing BAP was not obtained yet, because of the growth of somatic embryos on the highest of BAP was given in this research was still increase.

The initial cell density of culture was an important factor of growth needed to obtain maximum growth of cells in liquid medium. Culture with high cell density accelerate the proliferation and vice versa. High cell density absorbed nutrients faster in liquid medium than lower cell density. However, when the number of cells of somatic embryo in liquid medium had already maximum, the cell proliferation should automatically inhibited, because an imbalance between media and nutrients for cell in the medium [7]. The decrease of cell proliferation might also caused by the use of prolonged liquid media which accumulated toxic compound [8].

Previous study reported that prolonged incubation period caused the color changes of media and became finally decreased cell proliferation. Incubation period was also determined cell growth of somatic embryo in liquid media [2]. Culturing somatic embryo for too long period in liquid cultuer caused disturbance of osmotic process within the cell, therefore the water content of somatic embryo became very low. It became one of the factors that decrease proliferation of somatic embryo in liquid culture [10].

The growth regulators BAP in the culture media stimulated cell proliferation in some species. A range different BAP concentration has been used to induce somatic and embryogenesis shoot regeneration of citrus and Chrysanthemum [11]. Multiplication of somatic embryos in Chrysanthemum showed the best growth at media containing suplement of $1.0 \mathrm{mgL}^{-1}$ BAP [11], whereas in $C$. aurantifolia and $C$. sinensis at media with concentration of 1.5 and $2 \mathrm{mgL}^{-1} \mathrm{BAP}$. The higher concentrations of BAP in liquid culture had a negative effect on embryogenic cell growth. The addition of $3 \mathrm{mgL}^{-1}$ BAP into liquid media descreased the growth of somatic embryo in $C$. suhuinensis [2]. Liquid culture system significantly accelerated multiplication of somatic embryo, thus it has a promising potential as micropropagation technique in citrus trought somatic embryogenesis.

\section{CONCLUSION}

The optimum growth of somatic embryo in citrus mandarin were obtained at initial cell density of $10 \mathrm{mgL}^{-1}$ and $6^{\text {th }}$ incubation period culture. Addition of plant growth regulator BAP on media increased multiplication of Citrus somatic embryo in liquid culture.

\section{REFERENCES}

[1] Hardiyanto, A. Supriyanto. 2010. Jeruk mandarin variety Batu 55. Indonesian Citrus and Subtropical Fruit Research Institute. Malang. 
[2] Agrisimanto, D., N.M. Noor, Ibrahim R., A. Mohamad. 2010. Efficient somatic embryo production of Limau Madu (Citrus suhuinensis Hort. Ex Tanaka. African J. Biotech. 11. 2879-2888.

[3] Al Taha, H.A.K., A.M. Jasim, M.F. Abbas. 2012. Somatic embryogenesis and plantlet regeneration from nucleus tissues of local orange (Citrus sinensis (L.) Osbeck). Acta Agr. 99 (2). 185-189.

[4] Devy, Y., Hardiyanto. 2012. Perbanyakan massal embrio kalamondin melalui teknologi somatik embriogenesis melalui bioreaktor. Jurnal Holtikultura. 22(1). 1-7.

[5] Kobayashi, T., K. Higashi, H. Kamada. 2001. Stimulatory and inhibitory conditioning factors that regulate cell proliferation and morphogenesis in plant cell culture. Rev. Plant Biotech. 18(2). 93-99.

[6] Vantu, S. 2008. Somatic embryogenesis in Rubbus caesius L. suspension cultures. J. Biol. Veg. 2 (2). 104-108.

[7] Mukhtar, R., M.M. Khan, R. Rafiq, A. Shahid, F.A. Khan. 2005. In Vitro regeneration and somatic embryogenesis in Citrus aurantifoliaand Citrus sinensis. Int. J. Agr. Biol. 7(3). 518-520.

[8] Moiseeva, N.A., Y.N. Serebryakova, L. Nardi, S. Lucretti, Butekno R.G. 2006. Organization of initial stages of somatic embryogenesis in tissue culture of Citrus Sinensis cv. Taracco at the organism level. Russ. J. Plant Physiol. 53. 548-555.

[9] Widoretno, W., C. Martasari, F.F. Nirmala. 2013. Pengaruh sukrosa dan fotoperiode terhadap embriogenesis Jeruk Mandarin Batu 55 (Citrus reticulata Blanco). J. Hortic. Indonesia. 4. 44-53.

[10] Umehara, M., S. Ogita, H. Sasamoto, H. Kamada. 2004. Inhibitory Factors of somatic embryogenesis regulated suspesion culture of Japanes Larch (Larix leptolepis Gordon). Plant Biotech. 21 (2). 87-94.

[11] Mani, T., K. Senthil. 2011. Multiplication of Chrysanthemum trough somatic embryogenesis. Asian J. Pharm. Tech. 1 (1). 13-16. 